\title{
APLIKASI PEMANTAUAN STATUS GIZI BERDASARKAN PENGUKURAN ANTROPOMETRI MENGGUNAKAN METODE FUZZY LOGIC
}

\author{
Diska Yunita Sari ${ }^{1}$, , Wahyu K. Dewanto, ${ }^{2}$ Surateno $^{3}$ \\ 1. Mahasiswa Politeknik Negeri Jember, Program studi MIF \\ 2. Dosen Politeknik Negeri Jember, Jurusan Teknologi Informasi, Program studi MIF \\ 3. Dosen Politeknik Negeri Jember, Jurusan Teknologi Informasi, Program studi Teknik Komputer
}

\begin{abstract}
ABSTRAK
The problem of malnutrition in adults (age 18 years and over) is an important issue, because in addition to having the risk of certain diseases, can also affect work productivity. Therefore, monitoring of the situation needs to be done on an ongoing basis. One way is to maintain ideal or normal weight. Nutritional status is a description of the balance between nutritional intake with the needs of the body individually. Basically nutritional status is influenced by many factors that is food consumption, parent education, parent income, and awareness of parents about the importance of nutritional problems, but the dominant factor is the factor of food consumption. Anthropometry is one method that can be used in Universal, inexpensive to measure the size, part, and composition of the human body. Anthropometry is important for public health and can affect health and social well-being. In addition, anthropometry applications can be used to assess growth status, nutritional status and obesity, exercise, technique and advanced age.
\end{abstract}

Kata kunci : aplikasi, sensus harian, rawat inap, rumah sakit umum Kaliwates Jember.

\section{PENDAHULUAN}

Masalah kekurangan gizi pada orang dewasa (usia 18 tahun keatas) merupakan masalah penting, karena selain mempunyai resiko penyakit-penyakit tertentu, juga dapat mempengaruhi produktifitas kerja. Oleh karena itu, pemantauan keadaan tersebut perlu dilakukan secara berkesinambungan. Salah satu cara adalah dengan mempertahankan berat badan yang ideal atau normal.

Status gizi merupakan deskripsi keseimbangan antara asupan gizi dengan kebutuhan tubuh secara individual. Pada dasarnya status gizi dipengaruhi oleh banyak faktor yaitu konsumsi makanan, pendidikan orang tua, pendapatan orang tua, dan kesadaran orang tua tentang pentingnya masalah gizi, akan tetapi akan tetapi faktor yang dominan adalah faktor konsumsi makanan.

Antropometri merupakan salah satu metode yang dapat dipakai secara universal, tidak mahal untuk mengukur ukuran, bagian, dan komposisi tubuh manusia. Antropometri penting untuk kesehatan masyarakat dan dapat mempengaruhi kesehatan dan kesejahteraan sosial. Selain itu, aplikasi antropometri dapat dipakai untuk menilai status pertumbuhan, status gizi dan obesitas, olah raga, teknik dan lanjut usia.

Secara teori sudah ada cara untuk menghitung nilai gizi dan menentukan status gizi berdasarkan IMT, namun perhitungan dan penentuan status gizi tersebut menggunakan himpunan tegas (crips). Pada himpunan tegas, jika terjadi perubahan yang kecil saja terhadap nilai akan mengakibatkan perbedaan kategori. Hal ini sangat kaku, sehingga perubahan tersebut akan mempengaruhi status gizi. Jika status gizi berubah maka penanganan terhadap pasien juga berubah. Himpunan fuzzy digunakan untuk mengantisipasi hal tersebut, karena dapat memberikan toleransi terhadap nilai sehingga dengan adanya perubahan sedikit pada nilai tidak akan memberikan perbedaan yang signifikan.

N. Fidiantoro dan T. Setiadi (2013) melakukan perhitungan $z$ score untuk penentuan status gizi balita. Indikator yang digunakan dalam penelitian ini diantaranya berat badan menurut umur $(\mathrm{BB} / \mathrm{U})$, tinggi badan menurut umur $(\mathrm{TB} / \mathrm{U})$, dan berat badan menurut tinggi (BB/TB). Metode untuk menilai kepastian status gizi menggunakan fuzzy logic sehingga dapat menentukan status gizi balita dengan lebih baik yang disertai dengan nilai derajat keanggotaan.

F. Wulandari dan I. Yuliandri (2014) dalam jurnal ilmiahnya melakukan pengelompokan 
pengguna berdasarkan kategori indeks massa tubuh (IMT), yakni kurus, normal, dan gemuk. Pengelompokan ini dikarenakan tiap kategori IMT memiliki kemungkinan penyakit yang diderita berbeda. Sistem ini bekerja dengan melakukan diagnosa berdasarkan gejala - gejala penyakit yang dirasakan oleh pengguna, lalu melakukan perhitungan berdasarkan nilai Certainty Factor dari masing - masing gejala yang ada.

Kedua penelitian diatas mendukung alasan untuk dilakukan pengukuran antropometri sebagai penilaian status gizi. Dalam proposal ini diusulkan sebuah penilaian status gizi berdasarkan pengukuran antropometri dengan metode fuzzy logic untuk membantu mengatasi masalah gizi. Pada kegiatan ini data yang digunakan adalah data-data antropometri yaitu berat badan (BB) dan tinggi badan (TB). Sedangkan pengelompokan berdasarkan indeks massa tubuh yakni gizi sangat kurang, gizi kurang, gizi normal, gizi lebih, dan gizi sangat lebih.

\section{Tujuan}

Tujuan umum dari kegiatan ini adalah untuk mengetahui status gizi pada orang dewasa dengan pengukuran antopometri dan membantu pengembangan sistem dalam pengukuran atropometri di puskesmas sehingga pemantauan status gizi dapat dilakukan secara efektif. Pengukuran dapat dilakukan dimana saja dengan online menggunakan website sehingga pengukuran status gizi tidak hanya dilakukan dirumah sakit ataupun di puskesmas tetapi juga dapat dilakukan di rumah. Dengan mengukur status gizi dengan parameter indeks massa tubuh (IMT) dengan variabel berat badan(BB), dan tinggi badan (TB). Pengukuran dapat dilakukan menggunakan timbangan injak seca untuk mengukur berat badan, dan alat pengukur tinggi badan untuk mengukur tinggi badan sehingga dapat dilakukan dengan mudah di rumah.

\section{METODE}

Pembuatan Skripsi yang berjudul Aplikasi Pemantauan Status Gizi Berdasarkan Pengukuran Antropometri Menggunakan Metode Fuzzy Logic ini menggunakan desain penelitian kualitatif dengan tahapan sebagai berikut: a. Identifikasi permasalahan yaitu mengetahui dan menentukan masalah yang akan dibahas pada penelitian ini yaitu masalah tentang pemantauan status gizi di Puskesmas Jember Kidul yang secara manual sehingga dapat menyebabkan resiko kesalahan entry data dan kesalahan perhitungan.

b. Melakukan studi pustaka dan pengumpulan data dengan menggunakan metode observasi dan wawancara.

c. Hasil dari penelitian tersebut akan menjadi rencana awal pengembangan dan penelitian agar dapat diaplikasikan untuk langkah kedepannya di Puskesmas Jember Kidul.

Dari tahapan tersebut maka metode yang lebih cocok adalah menggunakan metode waterfall.

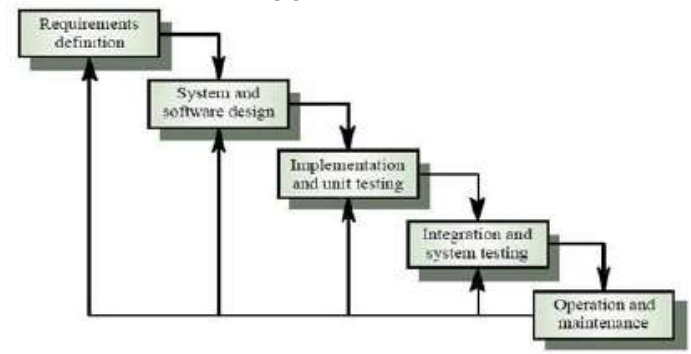

Metode kegiatan yang dipakai adalah metode Waterfall menurut referensi Sommerville (2001) Seperti yang ditinjau pada Gambar 3.1, Metode Waterfall adalah suatu proses pengembangan perangkat lunak berurutan, di mana kemajuan dipandang sebagai terus mengalir ke bawah (seperti air terjun) melewati fase-fase perencanaan, pemodelan, implementasi (konstruksi), dan pengujian.

\section{HASIL DAN PEMBAHASAN 3.1 Analisis Kebutuhan Sistem}

Tahap ini merupakan tahap menganalisa kebutuhan-kebutuhan yang dibutuhkan dalam penentuan data antropometri dengan memperhatikan kebutuhan pada lingkungan sekitar daerah penelitian. Pada tahap ini proses pengambilan data dilakukan dengan cara melakukan survei dan wawancara dengan bertanya langsung kepada petugas puskesmas poli lanjut usia mengenai pengukuran status gizi pada lanjut usia dan proses penghitungan indeks massa tubuh (IMT) yang ada pada Puskesmas Jember Kidul. Selanjutunya menentukan parameter yang menjadi acuan dalam proses pembuatan sistem pemantauan status gizi pada 
orang dewasa. Setelah menganalisis, adapun permasalah yang terjadi yaitu permasalahan yaitu penyimpanan data perhitungan status gizi yang dilakukan di puskesmas sangan tidak efektif dan efisien dikarenakan pendataan dan penyimpanan data dilakukan dengan pencatatan di buku besar. Sehingga menimbulkan ketidak efisienan waktu saat pencariaan data dan resiko kehilangan data sangat besar. Untuk mengetahui gizi ideal pada lanjut usia dapat dilakukan dengan menghitung dengan rumus indeks massa tubuh (IMT).

Indeks Massa Tubuh $(I M T)=$ Berat Badan $(\mathrm{kg})$ (Tinggi Badan $(m))^{2}$

\begin{tabular}{ccccc}
\hline Variabel & Himpunan & Domain & $\begin{array}{c}\text { Fungsi } \\
\text { Keanggotaan }\end{array}$ & Parameter \\
\hline Berat & Ringan & {$[35,55]$} & Bahu kiri & $(35 ; 40 ; 55)$ \\
badan & Normal & {$[45,65]$} & Segitiga & $(45 ; 55 ; 65)$ \\
(kg) & Berat & {$[55,80]$} & Bahukanan & $(55 ; 75 ; 85)$ \\
Tinggi & Rendah & {$[145,165]$} & Bahu kin & $(145 ; 150 ; 165)$ \\
badan & Normal & {$[150,175]$} & Segitiga & $(150 ; 165 ; 175)$ \\
$(\mathrm{cm})$ & Tinggi & {$[160,190]$} & Bahukanan & $(160 ; 175 ; 190)$ \\
& Kurus tingkat berat & {$[13,17]$} & Bahu kin & $(13 ; 16 ; 17)$ \\
& Kurus tingkat ringan & {$[16,18.5]$} & Trapesium & $(16 ; 17 ; 17.5 ; 18.5)$ \\
Nilai & Normal & {$[17.5,25]$} & Trapesium & $(17.5 ; 18.5 ; 24 ; 25)$ \\
Gizi & Gemuk tingkat ringan & {$[24,27]$} & Trapesium & $(24 ; 25 ; 26 ; 27)$ \\
& Gemuk tingkat berat & {$[26,33]$} & BahuKanan & $(26 ; 27 ; 33)$ \\
\hline
\end{tabular}

Himpunan fuzzy beserta fungsi keanggotaan dari variabel berat badan, tinggi badan, dan nilai gizi sebagai berikut:

a. Himpunan Fuzzy Variabel Berat Badan Pada variabel berat badan didefinisikan tiga himpunan fuzzy, yaitu ringan, normal, dan berat. Variabel berat badan digunakan bentuk kurva bahu kiri untuk himpunan fuzzy ringan, bentuk segituga untuk himpunan fuzzy normal, dan bentuk kurva bahu kanan untuk himpunan fuzzy berat. Gambar himpunan fuzzy untuk variabel berat badan.

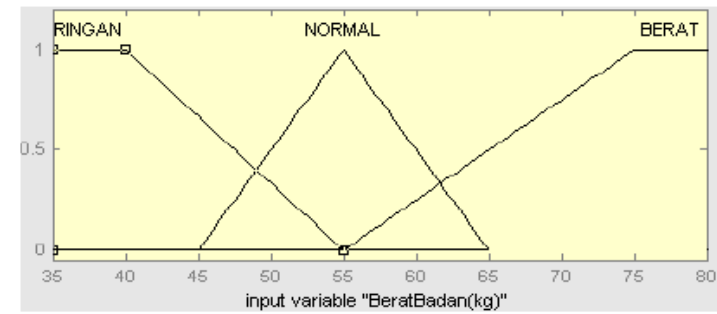

Sumbu horizontal merupakan nilai input dari variabel berat badan, sedangkan sumbu vertikal merupakan tingkat keanggotaan dari nilai

input.

$$
\begin{gathered}
\mu \text { Ringan }=\left\{\begin{array}{c}
1 ; x \leq 40 \\
\frac{55-x}{15} ; 40 \leq x \leq 55 \\
0 ; x \geq 55
\end{array}\right. \\
\mu \text { Normal }=\left\{\begin{array}{c}
0 ; x \leq 45 \\
\frac{x-45}{10} ; 40 \leq x \leq 55 \\
\frac{65-x}{10} \quad ; 55 \leq x \leq 65 \\
0 ; x \leq 65
\end{array}\right.
\end{gathered}
$$$$
\mu \text { Berat }=\left\{\begin{aligned}
0 ; x & \leq 55 \\
\frac{x-55}{20} ; & 55 \leq x \leq 75 \\
1 ; x & \geq 75
\end{aligned}\right.
$$

b. Himpunan Fuzzy Variabel Tinggi Badan Pada variabel tinggi badan didefinisikan tiga himpunan fuzzy, yaitu rendah, normal, dan tinggi. Untuk mempresentasikan variabel tinggi badan digunakan bentuk kurva bahu kiri untuk himpunan fuzzy rendah, bentuk kurva segitiga untuk himpunan fuzzy normal, dan bentuk kurva bahu kanan untuk himpunan fuzzy tinggi.

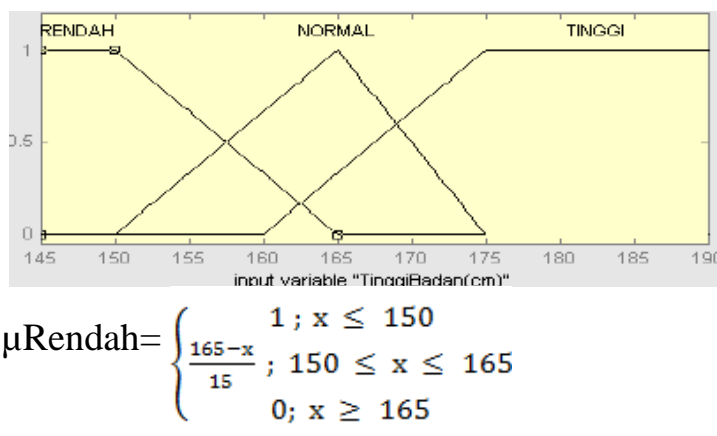

$$
\mu \text { Normal }=\left\{\begin{array}{c}
0 ; x \leq 150 \\
\frac{x-150}{15} ; 150 \leq x \leq 165 \\
\frac{175-x}{10} \quad ; 165 \leq x \leq 175 \\
0 ; x \geq 175
\end{array}\right.
$$$$
\mu \text { Tinggi }=\left\{\begin{array}{c}
0 ; x \leq 160 \\
\frac{x-160}{15} \quad ; 160 \leq x \leq 175 \\
1 ; x \geq 175
\end{array}\right.
$$

\section{c. Himpunan Fuzzy Variabel Nilai Gizi} Himpunan fuzzy nilai gizi diperoleh berdasarkan klasifikasi pada indeks massa tubuh (IMT), pada variabel nilali gizi didefinisikan lima himpunan fuzzy yaitu gizi sangat kurang, gizi kurang, gizi normal, gizi lebih dan gizi sangat lebih. Gambar himpunan fuzzy indeks massa tubuh. 


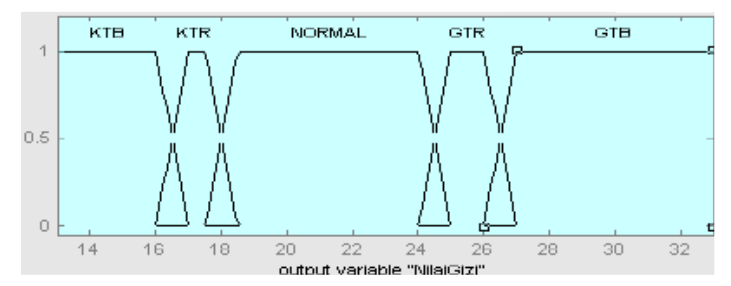

Sumbu horizontal merupakan nilai output nilai input dari variabel nilai gizi, sedangkan sumbu vertikal merupakan tingkat keanggotaan dari nilai input.

$\mu$ gizi sangat kurang $=\left\{\begin{aligned} 1 & ; x \leq 16 \\ 17-x ; & \quad 16 \leq x \leq 17 \\ 0 & ; x \geq 17\end{aligned}\right.$

$\mu$ gizi kurang $=\left\{\begin{array}{c}0 ; \mathrm{x} \leq 16 \\ x-16 ; 16 \leq \mathrm{x} \leq 17 \\ 1 ; 17 \leq \mathrm{x} \leq 17.5 \\ 18.5-x ; 17.5 \leq x \leq 18.5 \\ 0 ; x \geq 18.5\end{array}\right.$

pnormal $=\left\{\begin{array}{c}0 ; x \leq 17.5 \\ x-17.5 ; 17.5 \leq x \leq 18.5 \\ 1 ; 18.5 \leq x \leq 24 \\ 25-x ; 24 \leq x \leq 25 \\ 0 ; x \geq 25\end{array}\right.$

$\mu$ gizi lebih $=\left\{\begin{array}{c}0 ; x \leq 24 \\ x-24 ; 24 \leq x \leq 25 \\ 1 \quad ; 25 \leq x \leq 26 \\ 27-x ; 26 \leq x \leq 27 \\ 0 ; x \geq 27\end{array}\right.$

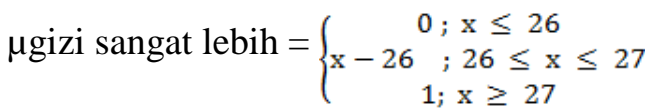

Contoh Kasus, seseorang dengan berat badan 60 dan tinggi badan $155 \mathrm{~cm}$ ingin mengetahui status gizinya. Berikut merupakan langkahlangkahnya:

Langkah 1 Menentukan Himpunan Fuzzy

Berat badan $60 \mathrm{~kg}$ termasuk kedalam himpunan fuzzy normal sekaligus berat dengan tingkat keanggotaan seperti persamaan 4.3 dan 4.4. maka:

$\mu$ Normal $=\left\{\begin{array}{c}0 ; x \leq 45 \\ \frac{x-45}{10} ; 40 \leq x \leq 55 \\ \frac{65-x}{10} \quad ; 55 \leq x \leq 65 \\ 0 ; x \leq 65\end{array}\right.$

$\mu$ Berat $=\left\{\begin{aligned} 0 ; x & \leq 55 \\ \frac{x-55}{20} ; & 55 \leq x \leq 75 \\ 1 ; x & \geq 75\end{aligned}\right.$

Sehingga diperoleh :

$\mu$ ringan $(60)=0$

$\mu$ normal $(60)=\frac{65-60}{10}=0.5$ $\mu$ berat $(60)=\frac{60-55}{20}=0.25$

yang berati bahwa berat badan orang tersebut dikatakan normal dengan tingkat $50 \%$ dan berat dengan tingkat $25 \%$.

Untuk tinggi badan $155 \mathrm{~cm}$ termasuk himpunan fuzzy rendah dan normal dengan tingkat keanggotaan seperti persamaan 4.5 dan 4.6:

$$
\begin{gathered}
\mu \text { Rendah }=\left\{\begin{array}{c}
1 ; x \leq 150 \\
\frac{165-x}{15} ; 150 \leq x \leq 165 \\
0 ; x \geq 165
\end{array}\right. \\
\mu \text { Normal }=\left\{\begin{array}{c}
0 ; x \leq 150 \\
\frac{x-150}{15} ; 150 \leq x \leq 165 \\
\frac{175-x}{10} \quad ; 165 \leq x \leq 175 \\
0 ; x \geq 175
\end{array}\right.
\end{gathered}
$$

Sehingga diperoleh:

$$
\begin{aligned}
& \mu \text { Rendah }(155)=\frac{165-155}{15}=0.67 \\
& \mu \text { Normal }(155)=\frac{155-150}{15}=0.33 \\
& \mu \text { Tinggi }(155)=0
\end{aligned}
$$

yang berati bahwa berat badan orang tersebut dikatakan ringan dengan tingkat $67 \%$ dan normal dengan tingkat $33 \%$.

Langkah 2 Fungsi Implikasi

\begin{tabular}{lcccc}
\hline & & \multicolumn{3}{c}{ Berat Badan } \\
\cline { 3 - 5 } & & Ringan & Normal & Berat \\
\hline Tinggi & Rendah & GiziNormal & Gizi Lebih & Gizi Sangat Lebih \\
Badan & Normal & Gizi Kurang & Gizi Normal & Gizi Lebih \\
& Tinggi & Gizi Sangat Kurang & Gizi Kurang & Gizi Normal \\
\hline
\end{tabular}

[R1]: Jika berat badan ringan dan tinggi badan rendah maka status gizinya gizi normal.

[R2]: Jika berat badan ringan dan tinggi badan normal maka status gizinya gizi kurang.

[R3] : Jika berat badan ringan dan tinggi badan tinggi maka status gizinya gizi sangat kurang.

[R4] : Jika berat badan normal dan tinggi badan rendah maka status gizinya gizi lebih.

[R5] : Jika berat badan normal dan tinggi badan normal maka status gizinya gizi normal.

[R6] : Jika berat badan normal dan tingginya tinggi maka status gizinya gizi kurang.

[R7] : Jika berat badan berat dan tingginya rendah maka status gizinya gizi sangat lebih.

[R8] : Jika berat badan berat dan tingginya normal maka status gizinya gizi lebih

[R9] : Jika berat badan berat dan tingginya tinggi maka status gizinya gizi normal. 
Fungsi implikasi pada kasus ini menggunakan fungsi minimum yaitu dengan mengambil tingkat kenggotaan yang minimum dan variabel input sebagai outputnya. Berdasarkan aturan-aturan penentuan gizi tersebut, maka diperoleh:

[R4] : Jika berat badan normal dan tinggi badan rendah maka status gizinya gizi lebih.

$\alpha$-predikat 1

$=\mu$ berat badan normal $\cap \mu$ tinggi badan rendah

$=\min (\mu$ berat badan normal $(0.5), \mu$ tinggi badan rendah $(0.67)$

$=\min (0.5,0.67)=0.5$

$\mathrm{Z} 1 \rightarrow 27-z=0.5$

$27-0.5=\mathrm{z}$

$26.5=\mathrm{z}$

[R5] : Jika berat badan normal dan tinggi badan normal maka status gizinya gizi normal.

$\alpha$-predikat2

$=\mu$ berat badan normal $\cap \mu$ tinggi badan normal

$=\min (\mu$ berat badan normal $(0.5), \mu$ tinggi badan normal $(0.33)$

$=\min (0.5,0.33)=0.33$

$\mathrm{Z} 2 \rightarrow 25-z=0.33$

$25-0.33=\mathrm{z}$

$24,67=\mathrm{z}$

[R7] : Jika berat badan berat dan tingginya rendah maka status gizinya gizi sangat lebih. $\alpha$-predikat3

$=\mu$ berat badan berat $\cap \mu$ tinggi badan rendah $=\min (\mu$ berat badan berat $(0.25), \mu$ tinggi badan rendah $(0.67)$

$=\min (0.25,0.67)=0.25$

$\mathrm{Z} 3 \rightarrow \mathrm{z}-26=0.25$

$\mathrm{Z}=26+0.25$

$\mathrm{z}=26.5$

[R8] : Jika berat badan berat dan tingginya normal maka status gizinya gizi kurang

$\alpha$-predikat4

$=\mu$ berat badan berat $\cap \mu$ tinggi badan normal

$=\min (\mu$ berat badan berat $(0.25), \mu$ tinggi badan normal $(0.33)$

$=\min (0.25,0.33)=0.25$

$\mathrm{Z} 4 \rightarrow 18.5-z=0.25$

$18.5-0.25=\mathrm{z}$

$18.25=\mathrm{z}$

Langkah 3 Defuzzifikasi $z=\frac{\operatorname{\alpha pred}_{1} * z_{1}+\operatorname{\alpha pred}_{2} * z_{2}+\operatorname{\alpha pred}_{3} * z_{3}+\operatorname{\alpha pred}_{4} * z_{4}}{\text { opred }_{1}+\operatorname{opred}_{2}+\operatorname{\alpha pred}_{3}+\operatorname{\alpha pred}_{4}}$

$\mathrm{Z}$

$=0 . \overline{5 * 26.5+0.33 * 24.67+0.25 * 26.5+0.25 * 18.25}$

$0.5+0.33+0.25+0.25$

$\mathrm{z}=\frac{13.25+8.141+6.625+4.652}{1.33}$

$\mathrm{z}=\frac{32.668}{1.33}=24.562$

\subsection{Desain}

a. Desain Sistem Usecase

Setelah proses identifikasi dan analisis selesei selanjutnya mendesign sebuah rancangan yang akan digunakan untuk diimplementasiskan ke dalam sebuah program aplikasi berbasis komputer berupa sistem pemantauan status gizi pada lanjut usia. Sistem ini bertujuan untuk mempermudah para orang dewasa dan perawat dalam penghitungan dan pemantauan status gizi.

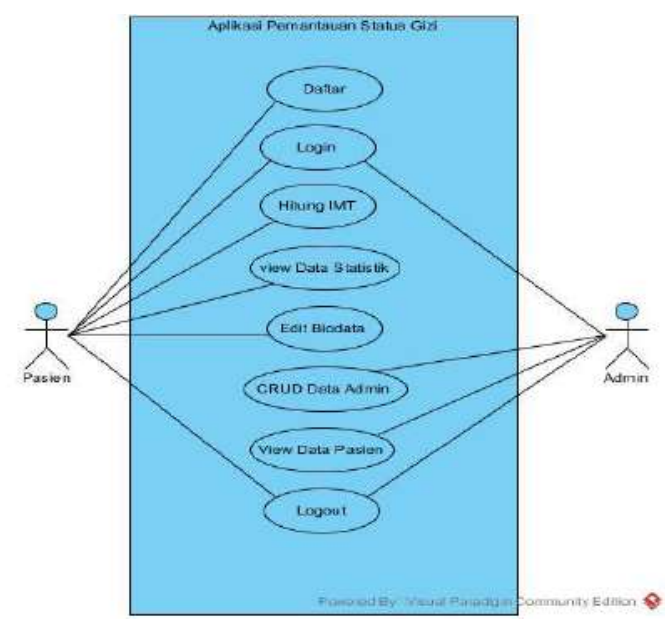

b. Desain Squence Diagram system komputerisasi Aplikasi Pemantauan Status Gizi Berdasarkan Pengukuran Antropometri.

Berikut adalah squence diagram sistem komputerisasi dari Aplikasi Pemantauan Status Gizi Berdasarkan Pengukuran Antropometri.

1) Squence Diagram Pendaftaran

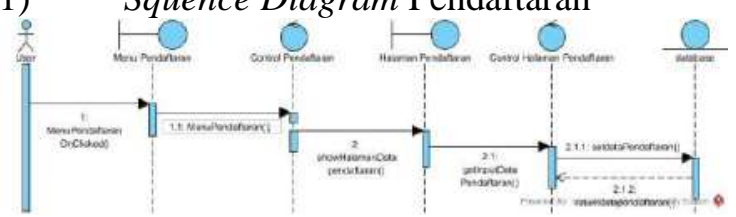

2) Squence Diagram Login 


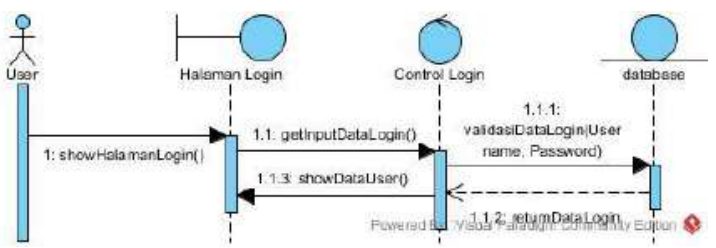

3)

Squence Diagram Hitung IMT

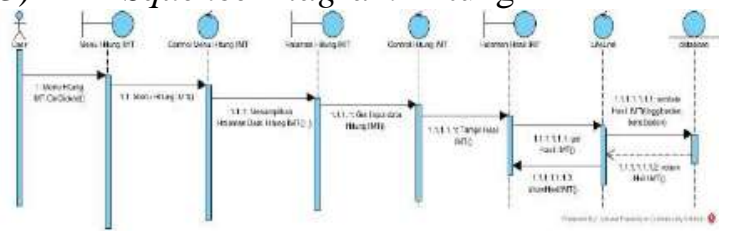

4) Squence Diagam Edit Biodata

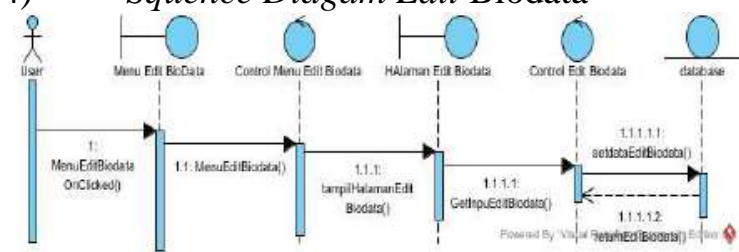

5) Squence Digram View Data Statistik

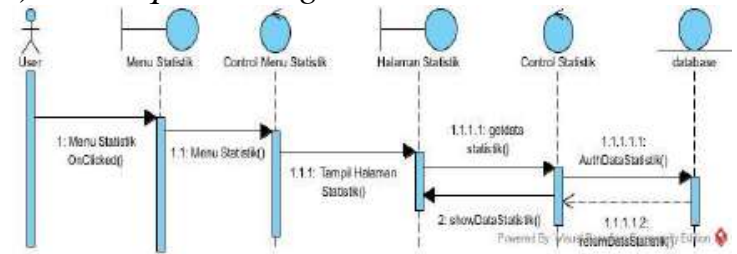

6) Squence Diagam CRUD Data Admin

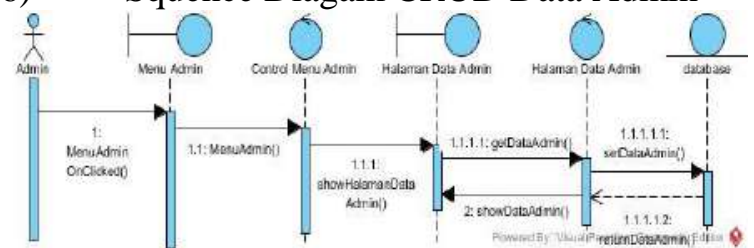

7) Squence Diagram View Data Pasien

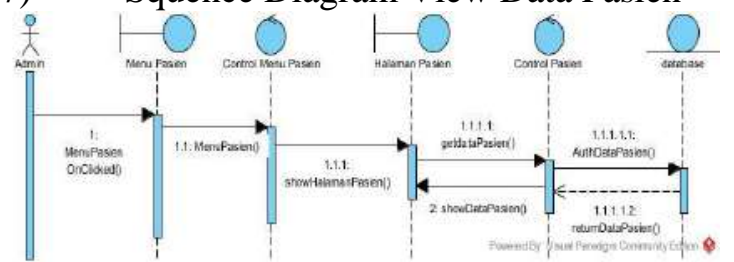

c. Class Diagram Aplikasi Pemantauan Status Gizi Berdasarkan Pengukuran Antropometri.

Class diagram menggambarkan struktur yang akan dibuat untuk merancang aplikasi. Kelas memiliki apa yang disebut dengan atribut dan metode atau operasi. Atribut merupakan variabel-variabel yang dimilikioleh suatu kelas sedangkan metode atau operasi adalah fungsifungsi yang dimiliki oleh suatu kelas. Berikut ini adalah Class Diagram dari Aplikasi Pemantauan Status Gizi Berdasarkan Pengukuran Antropometri.

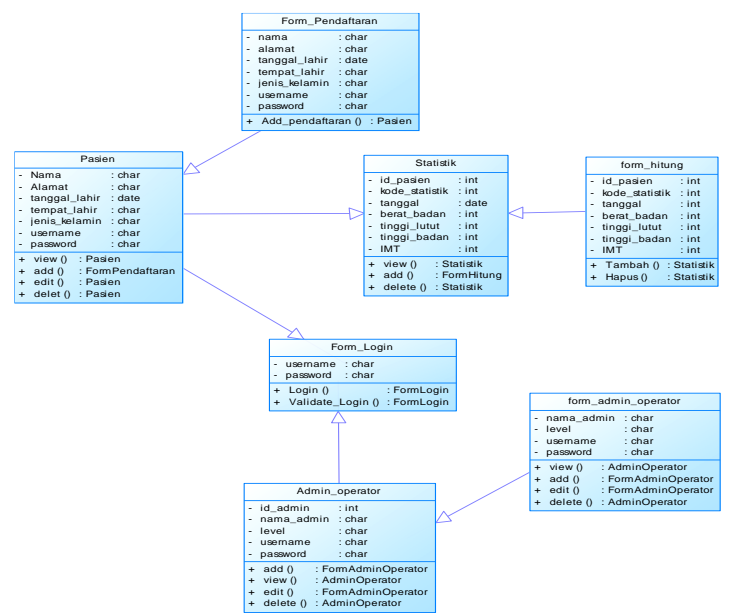

\subsection{Coding}

Pada tahapan ini dilakukan proses penerjemahan design yang telah dibuat dengan menggunakan web editor yaitu Adobe Dreamweaver 8. Kemudian syntax yang digunakan dalam pembuatan web ini yaitu.

a. HTML digunakan untuk menulis sebuah halaman website

b. PHP

c. CodeIgniter sebagai Framework dari pembuatan Website

d. Bootstrap merupakan desain website.

e. SQL sebagai database dari aplikasi.

\subsection{Testing}

Didalam tahap ini sistem informasi diuji dengan metode pengujian Blackbox. Pengujian sistem informasi ini dilakukan untuk mengetahui apakah desain interface telah sesuai dengan desain alur sistem, dan apakah sistem informasi ini mudah untuk digunakan oleh pengguna serta kebutuhan yang diharapkan pengguna telah sesuai.

a. Halaman Beranda

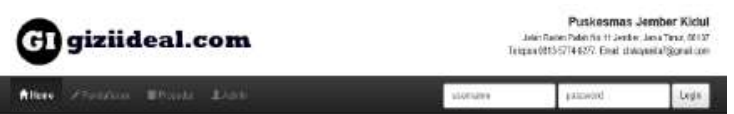

\section{Selamat Datang!}

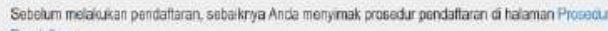

Dintrix

b. Halaman Prosedur 


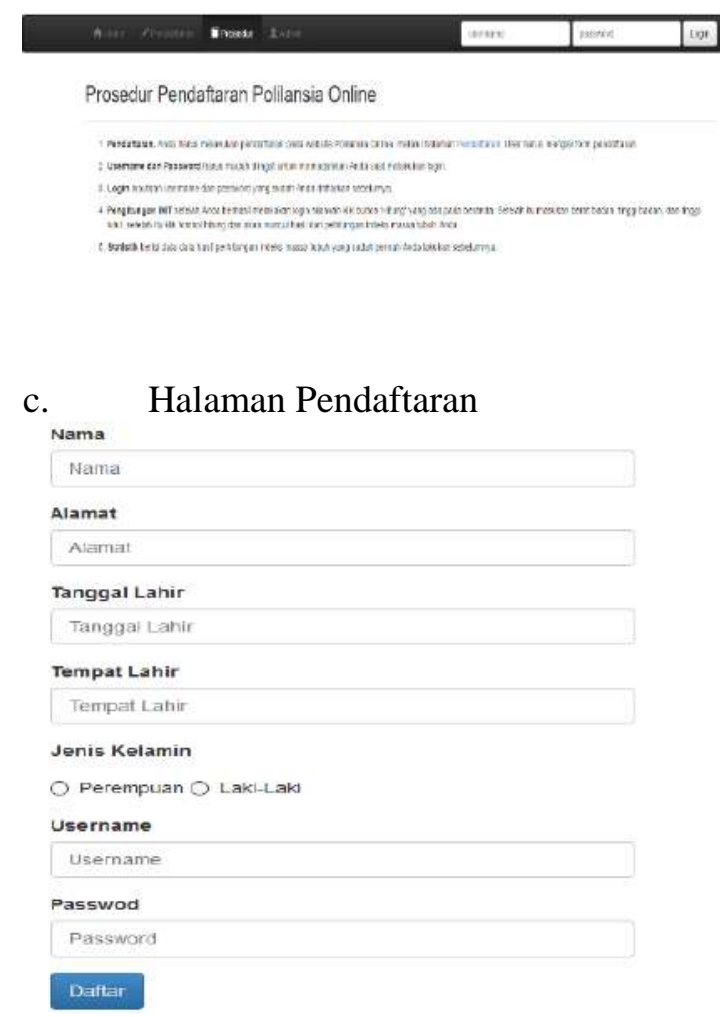

d. Halaman Pasien

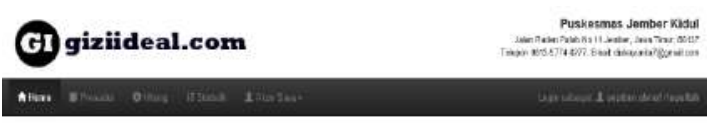

Selamat Datang!

\section{Hak, septian ahnaf risqullah}

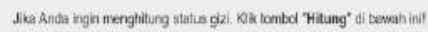

than

e. Halaman Login Eror Pasien

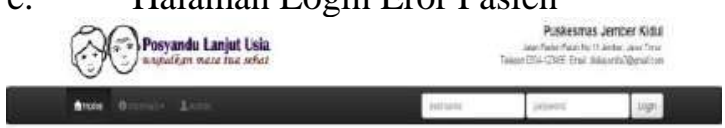

Login Error

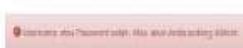

f. Halaman Form hitung

Hitung Indeks Massa Tubuh (IMT)

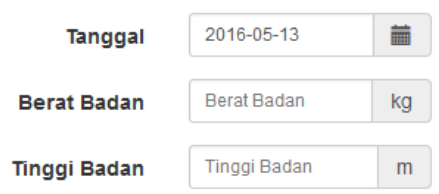

Data Statistik

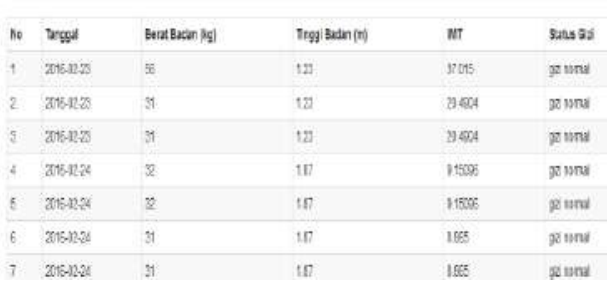

h. Halaman Edit Biodata

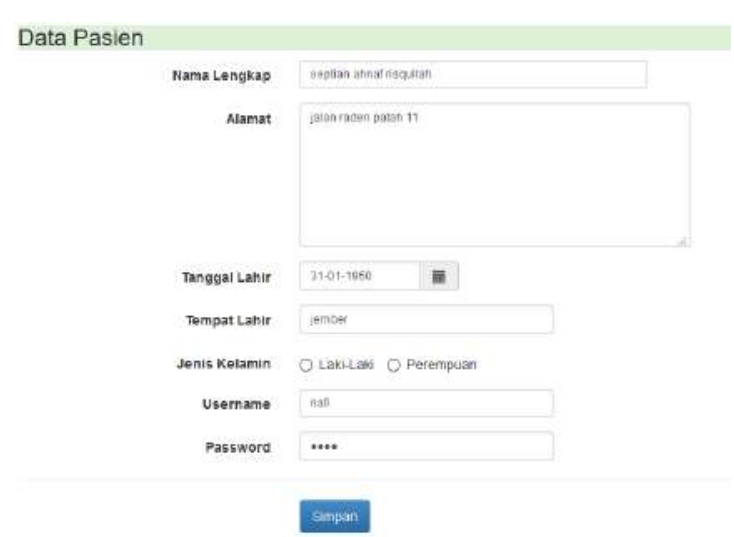

i. Halaman Login Admin

\section{Silakan login!}

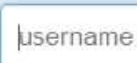

Password

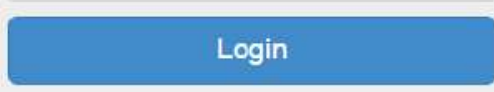

j. Halaman Admin

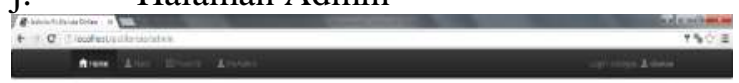

Selamat Datang!

How ofistan

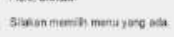

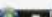

k. Halaman Data Pasien

g. Halaman Statistik 


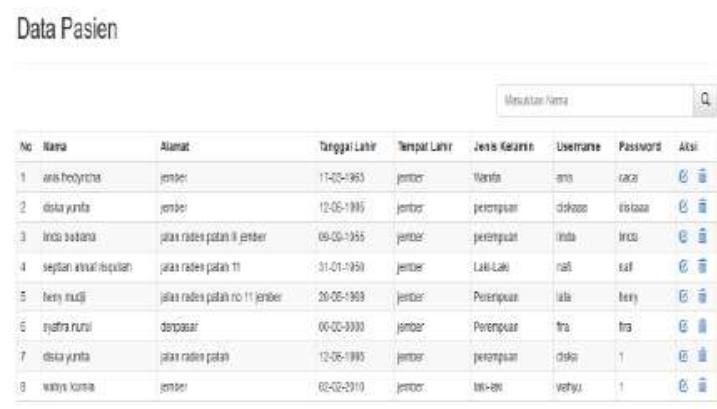

1. Halaman Form Tambah Admin

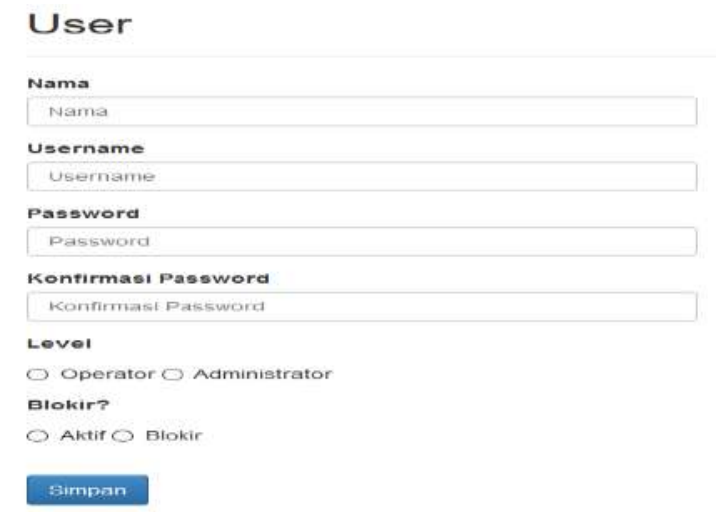

m. Halaman Data Admin

Data User

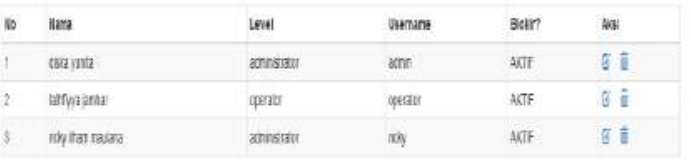

n. Halaman MyAdmin

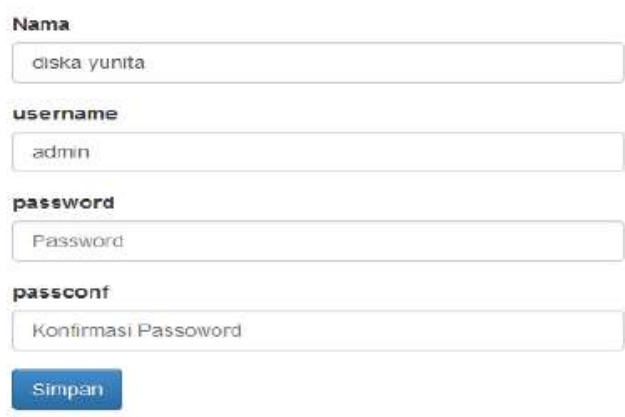

\section{KESIMPULAN DAN SARAN 4.1 Kesimpulan}

Kesimpulan dari penelitian ini adalah:

a. Berdasarkan analisis kebutuhan yang dilakukan di Puskesmas Jember Kidul, dan penginputan data pasien pun berpotensi terjadi kesalahan dalam penulisannya, serta memiliki banyak file laporan yang harus disimpan dan bertambah setiap harinya. Aplikasi Pemantauan Status Gizi Menggunakan Metode Fuzzy Logic telah dapat menyajikan informasi kedalam bentuk website sehingga dapat menghitung status gizi orang dewasa menggunakan metode fuzzy logic.

b. Aplikasi Pemantauan Status Gizi Menggunakan Metode Fuzzy Logic telah dapat digunakan untuk membantu menghitung status gizi sehingga pengaksesan tidak hanya dilakukan di puskesmas saja tetapi bisa dilakukan dimana saja dengan menggunakan website.

\subsection{Saran}

Saran yang dapat dikemukan dalam perancangan dan pembuatan aplikasi pemantauan status gizi berdasarkan pengukuran antropometri menggunakan metode fuzzy logic adalah:

a. Diharapkan adanya pengembangan dari program yang ada dengan penambahan fitur- fitur agar program menjadi lebih sempurna.

b. Diharapkan dapat di hubungkan meggunakan Aplikasi Android.

\section{DAFTAR PUSTAKA}

Adisty, C. 2012. Asuhan Gizi Nutritional Care Process. Graha Ilmu:Yogyakarta.

Fidiantoro dan Setiadi, 2010. Model Penentuan Status Gizi di Puskesmas. Universitas Ahmad Dahlan: Yogyakarta.

Fajri. 2013. Aplikasi Berbasis Web Untuk Pemantauan Status Gizi dan Tumbuh Kembang Anak Berdasarkan Data Antropometri.Universitas Diponegoro: Semarang.

Irianto, Djoko Pekik, 2012. Panduan Gizi Lengkap Keluarga dan Olahragawan. Yogyakarta.

Jogiyanto .2010. Analisis dan Desain Sistem Informasi, Edisi VI .Andi.Yogyakarta.

Kusumadewi, Sri. 2010. Aplikasi Logika Fuzzy. Graha Ilmu, Yogyakarta.

Noviansyah, Eka. 2012. Aplikasi Website Museum Nasional Menggunakan Macromedia Dreamweaver Mx4, STIK, Jakarta. 
Sutomo, Budi. 2010. Menu Sehat Alami untuk Batita dan Balita. Demedia:Jakarta.

Wulandari, Yogawati, 2011. Aplikasi Metode Mamdani Dalam Penentuan Status Gizi Dengan Indeks Massa Tubuh Menggunakan Logika Fuzzy. UNY: Yogyakarta.

Wulandari dan Yuliandri, 2014. Diagnosa Gangguan Gizi Menggunakan Metode Certainty Factor. UIN SUSKA: Riau. 